\title{
HOUSE FLY (Musca domestica L.) (DIPTERA: MUSCIDAE) DEVELOPMENT IN DIFFERENT TYPES OF MANURE
}

\author{
Patricia Larraín S. ${ }^{1}$, and Claudio Salas F. ${ }^{1}$
}

\begin{abstract}
A B S T R A C T
Animal production units with different management systems can be found along the Huasco Valley, Region of Atacama, Chile. These constitute sources of house flies (Musca domestica L.) and other vector fly species that cause damage to animals and nuisance problems in urban areas. In order to asses the importance of fly breeding sources, an experiment was carried out under laboratory conditions to evaluate different types of animal manure and composted swine manure. Time of larval development, larva mortality, pupa size, and weight and time of development to the adult stage were assessed. Results show that swine, poultry and calf manure produced a significantly higher number of adult flies, shorter life cycles and larger and heavier pupae. Cow, dog, goat and horse manure follow in effectiveness for fly production. Composted swine manure was totally ineffective for domestic fly development.
\end{abstract}

Key words: flies, animal manures, compost.

\section{INTRODUCTION}

The house fly represents a pest of great economic importance in livestock and poultry production, contaminating animal products and transmitting a variety of pathogenes to animals, as well as causing problems by invading residencial areas neighboring on livestock units, affecting the quality of life of these populations (Farkas et al., 1998).

While this insect is able to development in various substrates, such as human excrement, horse, bovine, swine, bird, sheep and goat dung, decomposing vegetal material, kitchen waste, cut grass and carrion (Cook et al., 1999), not all of these have the same importance in terms of quality for the development and reproduction of the insect, given that this variable depends on the chemical and biological characteristics of each substrate (Farkas et al., 1998). Consequently, it is important to establish an index of the main generating foci according to the physical and biological characteristics of the generating substrates.

The generation of this information can contribute to the optimization of a management plan in order to reduce the population of these insects, reducing the costs associated with flies control and improving the quality of life of the communities neighboring to livestock units.

The objective of the present study was to evaluate the development of the house fly in different organic substrates generated in the Huasco Valley.

\section{MATERIALS AND METHODS}

The study was carried out in the Entomology Laboratory of the Intihuasi Experimental Center of the Instituto de Investigaciones Agropecuarias (INIA), located in La Serena (29 $55^{\prime}$ lat. South; $71^{\circ}$ 14' long. West), Coquimbo Region, Chile.

\section{Breeding of house flies}

In order to obtain neonatal larvae, house flies were collected in February 2007, in Buena Esperanza (283' S; 7049’ W), Vallenar, the Atacama Region. The collected samples were transferred to Flanders batteries and were fed ad libitum with water with

\footnotetext{
${ }^{1}$ Instituto de Investigaciones Agropecuarias, Centro Regional de Investigación Intihuasi, Casilla 36-B, La Serena, Chile. E-mail: plarrain@inia.cl; csalas@inia.cl *Corresponding author. Received: 24 May 2007. Accepted: 10 August 2007.
} 
sugar. To favor oviposition, cotton soaked in equal parts of water and milk was added. The eggs obtained were transferred to Petri dishes with moistened absorbant paper, where they were kept until eclosion.

\section{Organic substrates}

The substrates used were obtained from different locations in the community of Vallenar, with less than $15 \mathrm{~h}$ elapsing from their obtaining until the moment of their being infested with house fly larvae. For their part, the manure was collected less than $5 \mathrm{~h}$ after been excreted by the animals.

Cow manure was collected in a dairy farm, where the diet was based on concentrates, alfalfa meal and corn silage. The calf manure came from animals fed on milk and rolled cereals. The horse manure was obtained from horses fed on a diet of alfalfa hay. The swine manure was collected from confined animals fed on a diet based on bran, corn grains and whey (cheese-making byproduct). The goat manure was collected from a stable with animals grazing a mixture of numerous vegetal species present in the zone, in particular espino (Acacia caven Molina), copao (Eulychnia acida Phil.) and residues from horticultural crops harvestings. The chicken manure came from birds fed on grains and insects, the dog feces or excrement was obtained from an animal fed on pellets, and the composted (mature) swine manure was obtained from intensive commercial plants (Agrícola Super Ltda.) located in the Metropolitan Region.

The methodology for the determination of the moisture of the substrates was based on that used by Farkas et al. (1998), exposing the material to a temperature of $103{ }^{\circ} \mathrm{C}$ for $3 \mathrm{~h}$.

In order to prevent the presence of diptera larvae at the time of collection, the samples were submitted to a temperature of $105^{\circ} \mathrm{C}$ for $15 \mathrm{~min}$ in a drying oven. Once the manure reached room temperature, the lost moisture was restored through the addition of distilled water based on weight difference.

\section{Treatments and experimental design}

The treatments were based on the use of eight organic substrates, distributed in a design of completely randomized blocks with four replicates. The treatments were the following: (T1) cow manure, (T2) nursing calf manure, (T3) horse manure, (T4) swine manure, (T5) goat manure, (T6) composted swine manure, (T7) dog feces and (T8) chicken manure.
The experimental unit consisted of $50 \mathrm{~g}$ of organic substrate placed in a $300 \mathrm{~mL}$ plastic container. The infestation of the treatments was done on February 9, 2007, with 30 neonatal house fly larvae $(<12$ h old) per replicate. The transference of the larve to each container was done using a No. 2 paintbrush to avoid damaging them.

Once each treatment was infested, the containers were placed in an isolated room in order to prevent oviposture of diptera as a product of attraction of the substrate. The average temperature of the room during the experimental period was $27-30^{\circ} \mathrm{C}$. The conditions of the photoperiod, until the emergence of adults, was $0: 24 \mathrm{~h}(\mathrm{~L}: \mathrm{D})$ and once adult emergence began it was $12: 12 \mathrm{~h}(\mathrm{~L}: \mathrm{D})$ in the same manner as was used by Farkas et al. (1998). Moisture was 65\%.

\section{Evaluation and data analysis}

Evaluations were made daily and were the following: duration of the larval state, mortality of larvae, weight and size of pupae and the time elapsed until the emergence of adult house flies.

The percentage of mortality was calculated in relation to the difference between infested larvae per substrate and adults obtained. Likewise, the determination of the percentage of emergence of adults considered only the surviving individuals of each of the treatments. The pupae were measured with calipers and were weighed with a precision scale.

The data obtained was statistically analysed using analysis of variance (ANOVA) at 5\% of probability. The measurements were separated using the least significant difference test (LSD) at $5 \%$ of probability through the statistical program SAS ${ }^{\circledR} 8.0$ (SAS Institute. 1999).

\section{RESULTS}

\section{Moisture of the substrates used}

The moisture content was: cow manure $78 \%$, milking calf manure $69 \%$, goat manure $68 \%$, swine manure $66 \%$, goat manure $56 \%$, composted swine manure $26 \%$, dog excrement $49 \%$ and chicken manure $65 \%$.

\section{Larval development}

The development time of the house fly larvae in milking calf, swine and chicken manure was significantly less $(\mathrm{P}<0.05)$ than in the other evaluated substrates (Table 1). In these manures, more than $83 \%$ 
Table 1. Average percentage of Musca domestica that reached the pupal stage at 6 and 10 days and larval mortality.

\begin{tabular}{lccc}
\hline Treatment & Pupae day 6 & Pupae day 10 & Larval mortality \\
\cline { 2 - 4 } & \multicolumn{3}{c}{} \\
\hline Cow manure & $5.0 \mathrm{c}$ & $84.2 \mathrm{~cd}$ & $16.7 \mathrm{~cd}$ \\
Calf manure & $83.3 \mathrm{a}$ & $89.2 \mathrm{bc}$ & $10.8 \mathrm{de}$ \\
Horse manure & $0.0 \mathrm{~d}$ & $81.2 \mathrm{~d}$ & $45.8 \mathrm{~b}$ \\
Swine manure & $97.5 \mathrm{a}$ & $97.5 \mathrm{a}$ & $2.5 \mathrm{f}$ \\
Goat manure & $0.0 \mathrm{~d}$ & $82.6 \mathrm{~cd}$ & $62.5 \mathrm{~b}$ \\
Composted swine manure & $0.0 \mathrm{~d}$ & $0.0 \mathrm{e}$ & $100.0 \mathrm{a}$ \\
Dog feces & $35.0 \mathrm{~b}$ & $79.2 \mathrm{~d}$ & $23.3 \mathrm{~cd}$ \\
Chicken manure & $93.3 \mathrm{a}$ & $95.0 \mathrm{ab}$ & $5.0 \mathrm{ef}$ \\
CV, \% & 14.4 & 3.3 & 24.3 \\
\hline
\end{tabular}

Measurements with different letters indicate significant differences according to the minimal significant differences test (DMS) $(\mathrm{P}<0.05)$.

of the larvae reached the pupal state in six days, and most notably in swine manure, in which the total of surviving larvae (98\%) developed in this period. On the other hand, only 5 and $35 \%$ of the larvae in dog feces and cow manure, respectively, reached the pupal state at 6 days. In the other organic substrates evaluated (horse and goat manure and composted swine manure) house fly larvae did not reach the pupal state in 6 days.

At 10 days after infestation, the majority of the larvae developed in cow, milking calf, chicken manure, and in dog feces had reached the pupal state (Table 1). The percentage of pupa formed at 10 days continued to be significantly greater $(\mathrm{P}<0.05)$ in the treatments based on swine and chicken manure, although in the latter substrate did not present any differences $(\mathrm{P}>$ $0.05)$ from the substrate based on calf manure. The treatment based on composted swine manure did not allow for the development of any larvae.

\section{Mortality}

In accordance with the results obtained from the duration of the larval development state, the mortality of larvae was significantly lower $(\mathrm{P}<0.05)$ in the treatment with swine manure $(2.5 \%)$ than in the other substrates evaluated, with the exception of chicken manure (5\%) (Table 1). This substrate was similar to that of calf manure, with a mortality of $11 \%$. This was followed by intermediate mortalities in treatments based on cow manure and dog feces. The treatments with horse and goat manure showed significantly greater mortalities $(\mathrm{P}<0.05)$ than the other treatments, with 46 and $63 \%$, respectively. Finally, composted swine manure did not allow larvae survival, reaching $100 \%$ of mortality.

\section{Size of pupae}

The development of a significantly greater size of pupae $(\mathrm{P}<0.05)$ was obtained in the treatments using swine and chicken manure, followed by the treatments with milking calf and cow manure (Table 2). This was followed by the pupae that developed in goat manure and $\operatorname{dog}$ feces, without significant differences between them $(\mathrm{P}<0.05)$. Notably, the pupae obtained in horse manure were of significantly smaller size than those obtained from the other manures evaluated (Figure 1).

\section{Weight of the pupae}

The weight of the pupae maintained the tendency observed in the measurement of size (Table 2), with the exception of those obtained with the treatment based on dog feces, which resulted in significantly greater weight $(\mathrm{P}<0.05)$ than those obtained from

Table 2. Average size and weight of Musca domestica pupae obtained in different animal manures.

\begin{tabular}{lcc}
\hline Treatment & $\begin{array}{c}\text { Size } \\
\mathbf{m m}\end{array}$ & $\begin{array}{c}\text { Weight } \\
\mathbf{m g}\end{array}$ \\
\hline Cow manure & $5.8 \mathrm{c}$ & $11.4 \mathrm{~d}$ \\
Calf manure & $6.2 \mathrm{~b}$ & $16.0 \mathrm{~b}$ \\
Horse manure & $4.9 \mathrm{e}$ & $8.4 \mathrm{e}$ \\
Swine manure & $6.5 \mathrm{a}$ & $20.0 \mathrm{a}$ \\
Goat manure & $5.1 \mathrm{~d}$ & $8.8 \mathrm{e}$ \\
Composted swine manure & $0.0 \mathrm{f}$ & $0.0 \mathrm{f}$ \\
Dog feces & $6.1 \mathrm{~b}$ & $14.0 \mathrm{c}$ \\
Chicken manure & $6.6 \mathrm{a}$ & $19.6 \mathrm{a}$ \\
CV, \% & 2.19 & 8.66 \\
\hline
\end{tabular}

Measurements with different letters indicate significant differences according to the minimal significant differences test (DMS) $(\mathrm{P}<0.05)$. 


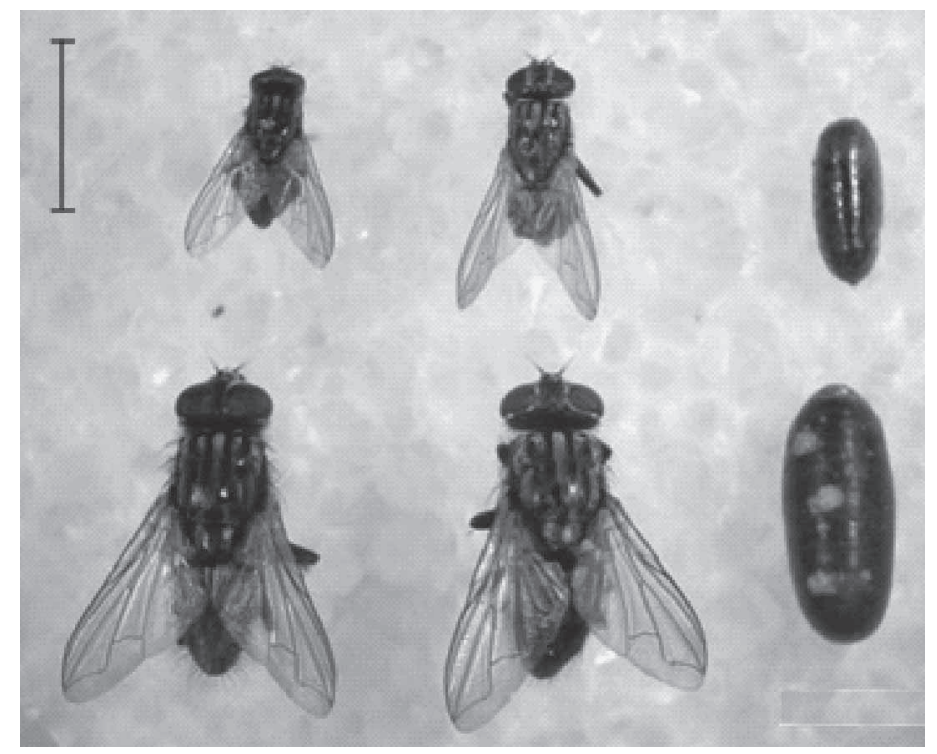

Figure 1. Size difference in adult Musca domestica obtained from horse manure (above) and swine manure (below). (Scale $=4 \mathrm{~mm}$ ).

cow manure, although the size of the pupae from this substrate was greater than of those obtained from dog feces.

\section{Emergence of adults}

The period elapsed between neonatal larvae and the emergence of adults was significantly less $(\mathrm{P}<0.05)$ in the treatments with swine, chicken and milking calf manure, reaching adulthood in only 11 days (Table 3).

Table 3. Average percentage of emergences of adult Musca domestica at days 11 and 15.

\begin{tabular}{lrr}
\hline Treatment & Day 11 & Day 15 \\
& & \\
\hline Cow manure & $2.9 \mathrm{c}$ & $100.0 \mathrm{a}$ \\
Calf manure & $73.2 \mathrm{a}$ & $100.0 \mathrm{a}$ \\
Horse manure & $0.0 \mathrm{c}$ & $98.8 \mathrm{a}$ \\
Swine manure & $88.8 \mathrm{a}$ & $100.0 \mathrm{a}$ \\
Goat manure & $0.0 \mathrm{c}$ & $96.2 \mathrm{a}$ \\
Composted swine manure & $0.0 \mathrm{c}$ & $0.0 \mathrm{~b}$ \\
Dog feces & $17.2 \mathrm{~b}$ & $100.0 \mathrm{a}$ \\
Chicken manure & $76.2 \mathrm{a}$ & $100.0 \mathrm{a}$ \\
CV, \% & 17.68 & 1.66 \\
\hline
\end{tabular}

Measurements with different letters indicate significant differences according to the minimal significant differences test (DMS) $(\mathrm{P}<0.05)$.
In the treatment with dog feces, less than $20 \%$ of the larvae completed the cycle on this period, while in those based on cow manure, the emergence of adults was less than $5 \%$. In the other substrates there was no emergence of adult flies. At 15 days, $100 \%$ of the total of pupae obtained in each substrate reached the adult state (Table 3 ).

\section{DISCUSSION}

The results obtained indicated that mature compost from swine manure does not allow the development of the house fly, registering larval mortalities of $100 \%$ with this treatment. This is due to the reduced moisture of the compost $(<30 \%)$ and the low nutritive value of composted material for the house fly larvae (Wortman et al., 2006). Both conditions are results of the composting process.

In effect, Moon et al. (2001) established that as a product of the rise of temperature in the composting process, the moisture of the organic material is reduced to levels below $40 \%$. These moisture levels do not permit the development of the house fly given that the optimum moisture for its development is in the range of 50 to $80 \%$, a condition that is supported by the present results. These same authors also point out that bacteria and other components that are used by the house fly larvae as source of nutrients decrease 
rapidly during the composting process. As well, the nutritive value of compost for the fly is reduced even more when the composting process has been completed. This correlation between low moisture and larval mortality could also occur in the treatment with dog feces, which has a moisture level of only $49 \%$ and a mortality rate of $46 \%$.

In relation to the duration of the larval state, Hogsette (1996) established that the moisture of the manure has a direct relationship to the duration of the larval and pupal states of flies. This is also indicated by Mullens et al. (2002), who carried out tests with species of Fanniidae. The current results showed the moisture by itself is not responsible for the reduction of the larval period, but rather is one of many components. Thus, the treatment with greater moisture (cow manure) concentrated the development of pupae 4 days later than the treatments with moisture up to $10 \%$ less.

The less efficient development of larvae in the treatments based on cow, horse and goat manure could be associated with the nutritive quality of their excrement, with a lower nitrogen content owing to diet with higher carbon and fiber content. The carbon/ nitrogen ratio $(\mathrm{C} / \mathrm{N})$ is lower, for example, in chicken excrement (7) than in cow excrement (12). Lower $\mathrm{C} / \mathrm{N}$ ratios increase the quality of the substrate and have greater microbiological activity, which is essential for the development of immature states of house flies, since, according to Ferrar (1987), the larvae of many species of muscoids feed more on the microorganisms that decompose organic material than on the same substrate. These results are contrary to what was established by Artigas (1994), who points out that fermented horse manure is the main and more efficient substrate for the development of house fly larvae.

Another component that should also be analyzed together with moisture content, chemical composition and the microflora of the manure is the size and surface/volume ratio of the manure. This parameter has relevance in the treatments based on goat manure, which, because of its reduced size and its high surface/volume ratio (Saíz. 1991), shows rapid drying and encrusting conditions that translate into a mortality rate of larvae of $63 \%$ (Table 1 ). The treatment based on horse manure, while it has a surface/volume ratio appropriate from the point of view of moisture retention, can owe its high percentage of mortality to the chemical composition since, as was registered, the individuals developed in it were of significantly lesser size.

With regard to obtaining flies of greater weight and size, Barnard et al. (1995) found a positive correlation between the phosphorus content of chicken manure and the size and weight of pupae, establishing that this element altered the chemistry and microflora of the manure, resulting that the larvae that feed on chicken manure with high concentrations of phosphorus develop puparia of greater size. Based on these results, it can be established that the swine and chicken manures evaluated have low concentrations of this element. Nevertheless, it is necessary to point out that this matter requires further research.

The low weight and size of the pupae developed in cow, goat and horse manure confirm a deficiency of nutrients during the larval development state. These biological parameters are of importance in the adaptation of the individuals, given that the fecundity of the females is significantly greater in individuals proceeding from pupae of greater size (Black and Krafsur. 1987).

\section{CONCLUSIONS}

The results obtained indicated that fresh swine, chicken and milking calf manure present better conditions for the development of the immature states of the house fly, reducing the larval period and generating progeny of greater size.

Excrement of livestock whose diet is based exclusively on vegetables and fiber (cows, goats and horses), has a lower quality for the development, survival and size of house flies. Mature compost based on swine manure does not allow for the development of this insect, owing to the low humidity and its low nutritive value for the fly, as a result of the composting process. 


\section{RESUMEN}

\section{Desarrollo de la mosca doméstica (Musca domestica} L.) (Diptera: Muscidae) en distintos tipos de estiércol. Patricia Larraín S. ${ }^{{ }^{*}}$, y Claudio Salas F. ${ }^{1}$ En algunas comunas del Valle del Huasco, Región de Atacama, Chile, se encuentran diversas explotaciones pecuarias con diferentes sistemas de manejo, las cuales constituyen focos generadores de mosca doméstica, Musca domestica L., y otras especies de moscas con importancia sanitaria y médica. Estos insectos provocan pérdidas económicas en dichos planteles afectando además el bienestar de poblaciones urbanas cercanas. Con el objetivo de cuantificar la importancia de dichos focos en la generación de mosca doméstica, se realizó un ensayo de laboratorio donde se evaluó como sustrato de desarrollo del insecto, estiércol de diferentes especies animales y estiércol de cerdo compostado. La calidad de estos sustratos en la producción del insecto se evaluó a través de los siguientes parámetros biológicos: tiempo de desarrollo de larvas, mortalidad de larvas, tamaño y peso de pupas, y tiempo hasta la emergencia de moscas adultas. Los resultados indicaron que el estiércol de cerdo, gallina y ternero produce significativamente más moscas adultas, con un ciclo de vida más corto y con pupas de mayor tamaño y peso. Luego siguen en efectividad en la producción de moscas, el estiércol de vaca, perro, cabra y caballo. El compost de estiércol de cerdo fue completamente inefectivo para el desarrollo de mosca doméstica.

Palabras clave: moscas, guano animal, estiércol, compost.

\section{LITERATURE CITED}

Artigas, J. 1994. Entomología económica. Insectos de interés agrícola, forestal, médico y veterinario. Vol. II. p. 280-284. Ediciones Universidad de Concepción, Concepción, Chile.

Barnard, D., R. Harms, and D. Sloan. 1995. Influence of nitrogen, phosphorus, and calcium in poultry manure on survival, growth, and reproduction in house fly (Diptera: Muscidae). Environ. Entomol. 24:12971301

Black, K., and E. Krafsur. 1987. Fecundity and size in the house fly: investigations of some environmental sources and genetic correlates of variation. Med. Vet. Entomol. 1:369-382.

Cook, D., I. Dadour, and N. Keals. 1999. Stable fly, house fly (Diptera: Muscidae), and other nuisance fly development in poultry litter associated with horticultural crop production. J. Econ. Entomol. 92:1352-1357.

Farkas, R., J. Hogsette, and L. Börzönyi. 1998. Development of Hydrotaea aenescens and Musca domestica (Diptera: Muscidae) in poultry and pig manure of different moisture content. Environ. Entomol. 27:695-699.

Ferrar, P. 1987. A guide to the breeding habits and immature stages of Diptera Cyclorrhapha. Entomonograph 8(1-2):907 p. E.J. Brill/Scandinavian Science Press, Leiden. Copenhagen.
Hogsette, J. 1996. Development of house flies (Diptera: Muscidae) in sand containing varying amounts of manure solids and moisture. J. Econ. Entomol. 89:940-945.

Moon, R., J. Hinton, S. O'Rourke, and D. Schmidt. 2001. Nutritional value of fresh and composted poultry manure for house fly (Diptera: Muscidae) larvae. J. Econ. Entomol. 94:1308-1317.

Mullens, B., C. Szij, and N. Hinkle. 2002. Oviposition and development of Fannia spp. (Diptera: Muscidae) on poultry manure low moisture levels. Environ. Entomol. 31:588-593.

Saíz, F. 1991. Fecas de herbívoros introducidos en Chile semiárido como hábitat para el desarrollo de insectos. Rev. Chil. Entomol. 19:59-64.

SAS Institute. 1999. SAS OnlineDoc ${ }^{\circledR}$, Version 8. SAS Institute Inc., Cary, North Carolina, USA.

Wortman, Ch., Ch. Shapiro, and D. Tarkalson. 2006. Composting manure and other organic residues. University of Nebraska-Lincoln Extension, Institute of Agriculture and Natural Resources, Lincoln, Nebraska, USA. Available at http://www.ianpubs. unl.edu/epublic/pages/index.jsp?what $=$ publication D\&publicationId=567 (Accessed 5 December 2007). 